\title{
Mutations: Foreword
}

\section{Marta Dvorak}

\section{(2) OpenEdition}

1 Journals

Electronic version

URL: https://journals.openedition.org/ces/8380

DOI: 10.4000/ces.8380

ISSN: 2534-6695

\section{Publisher}

SEPC (Société d'études des pays du Commonwealth)

\section{Printed version}

Date of publication: 1 April 2010

Number of pages: 3-4

ISSN: 2270-0633

\section{Electronic reference}

Marta Dvorak, "Mutations: Foreword", Commonwealth Essays and Studies [Online], 32.2 | 2010, Online since 17 December 2021, connection on 31 January 2022. URL: http://journals.openedition.org/ces/ 8380 ; DOI: https://doi.org/10.4000/ces.8380

\section{(c) (i) () $\Theta$}

Commonwealth Essays and Studies is licensed under a Licence Creative Commons Attribution - Pas d'Utilisation Commerciale - Pas de Modification 4.0 International. 


\section{FOREWORD}

This issue's international exchange of views, entitled Mutations, contributes to recent interrogations concerning postcolonial theory in mutation, unravelling and rearticulating itself within the contexts of an increasingly globalized world system. The contributors from multiple geopolitical and theoretical locations address in different ways the need to unsettle traditional postcolonial frameworks and engage with the frictional border-zones consubstantial with models of circulation: both inter- and intra-national migration and flow, of people, of ideas, of texts. The framing articles engage most clearly with texts which do not fit into the standard 'writing back' model of postcolonial intertextuality nor partake in a conventionalized anxiety of influence. They consider the complex dialogism staging the negotiations and conversions of space, time, and language, which range from (af)filiation (Niyi Osundare) to self-reflexive hypertextuality (Zadie Smith). The contributors set up a vexing, and thus fruitful, dialogue on the mystique of traditional culture and cultural continuity, foregrounding the intra-cultural fissures which challenge the social cohesion of older notions of mapping. Their remapping interrogates national imaginaries: they notably take into account the arbitrary nature of nation-states fashioned out of pre-existing kingdoms comprising multiple communities with discrete, often incompatible cultures and hereditary dissensions. By focusing on sub-national and supra-national communities in Africa, the South Pacific, and South Asia, these articles explore the cultural pluralism of a post-modern world, which Lyotard defined as a return to pre-modern ways of thinking. The authors address the literary configurations of crucial interrelations: nation and identity, but also religion and cultural nationalism. They engage with the return of spiritualities discernable in contemporary fictions of post-colonial regions, demonstrating how religions function as indigenizing, syncretic vehicles of identity. The study of the literary representations and misrepresentations of transnational shifting verbal-ideological belief systems is all the broader as it considers the Pan-African interzones of British and French decolonization through the prism of both anglophone and francophone writers from various African nation-states which have been subjected to the tensions and ruptures of intra-national migrations. It also engages with the transcultural dynamics of complex indigeneities and indigenizing processes such as those incurred by the Pakeha and non-European immigrant populations in New Zealand following the Maori Renaissance. Nor does it neglect the processes of cohabitation and interaction that have taken place in the revitalized literary landscape of Great Britain, where Black-British writing such as Zadie Smith's is now an important part of the whole picture, as the special issue Wasafiri 17 has celebrated.

This issue's focus on transitions and transformations with respect to both evolving disciplinary fields and framing global scene is interestingly intertwined with the encounter of Commonwealth writers in Delhi, the venue for the 2010 Commonwealth Writers' Prize, where Michael Crummey from the fishing community 
of Newfoundland, Canada, could debate the role of tradition with the young Nigerian writer Adaobi Tricia Nwaubani, shortlisted for her debut novel I Do Not Come to You by Chance. If Crummey writes to perpetuate an ancient oral storytelling tradition, Nwaubani is adamant about the need for artistic production to challenge the cultural traditions which she identifies as authoritarian, monological obstacles to new democratic, non-gendered modes of societal understanding. My participation in the round table organized by Delhi University, as a professor from the Sorbonne Nouvelle, was made possible by the visiting fellowship which I had been offered at Jawaharlal Nehru University's Institute of Advanced Study ${ }^{1}$. My presence at the side of these writers and critics from all areas of the globe encapsulates the plurality of fluctuating global/local, or glocal, entities with which people are confronted when they attempt to imagine how to live in the place they (currently) inhabit. Paying attention, as this issue does, to stories, to what and how people imagine, is ultimately productive, for, to borrow Michael Crummey's words, "These stories tell us who we are and, in the end, make us who we are."

Marta DVORAK Editor

1. I wish to thank Jawaharlal Nehru University's Institute of Advanced Study for the Visiting Fellowship 2009-10 during which this issue took shape, and which allowed me to work on three other book projects, including a co-edition with Diana Brydon, Crosstalk (autumn 2010). 